\title{
Castración y Lujos: La Escritura de Manuel Puig
}

\author{
al insinuar la duda de que acaso esten muertos los \\ hombres y los ninos que duermen en el suelo. . . \\ Oliverio Girondo
}

\begin{abstract}
Reino del mal gusto. Discurso de la cursilería. Agresión contra nuestra percepción de lo digno, lo verdadero, la noción de que las palabras forman parte de un sistema de castas. Complementariamente: anulación de un criterio de selección: esto es arte; aquello cosa perecedera, consumo. En fin, solución del problema del tabú por medio de la indiferencia ante la hipotética realidad de niveles, jerarquías. Todo es todo. No existe la posibilidad de contaminar aquello que no definimos como puro. Esto en Puig. Simultáneamente leemos una literatura que asume la heterogeneidad como principio de composición. Ejemplos: la escritura intrincada del Libro de Manuel, Rayuela, 62, Modelo para armar, el carácter mixto del idioma de Cambio de piel, Tres tristes tigres, etc. Pero, a pesar de todas las tentativas de autocrítica estamos aún leyendo Literatura cuando nos enfrentamos a estas novelas; somos lectores buenos ( $i$ buenos lectores?) en presencia de obras que tratan de efectuar una ruptura de su unidad argumental para asombrarnos ante la textura problemática de la ficción. Pero en estos autores este espacio no es el del mal gusto: la Maga lee a Galdós y el lector comparte una astuta sonrisa de burla con la voz que narra. No nos hemos despojado aun de la tranquilizadora máscara de lectores inteligentes, intelectuales. Estamos todavía en ese círculo íntimo de aquellos que gustan de literatura; la heterogeneidad es visible; está allí pero no problematiza la dignidad de lo que estamos leyéndo. ${ }^{1}$ Presencia literaria, problemas en un contexto que no cuestiona radicalmente las jerarquías de lo legible.
\end{abstract}

\footnotetext{
1 Al usar el término heterogeneidad indicamos que las novelas están compuestas de materiales de diversa calidad. Entre ellos se establece un juego que tiende a integrarlos dentro del texto marcando, al mismo tiempo, las características que los separan. En 62, Modelo para armar, por ejemplo, la primera aparición de un diálogo entre Calac y Polance es traducción al lenguaje coloquial de todo lo que antecede en la novela. La función de este diálogo es marcarse, inscribirse como traducción recortándose y parodiando las páginas que le anteceden. Hay ya una copiosa literatura en Hispanoamérica que asume la heterogeneidad cómo principio de composición y dibuja, así, un gesto que sugiere la proliferación de lenguajes como sustrato del texto.
} 
La obra de Puig, en cambio, prolijamente rechaza a aquellos lectores que buscan el "arte". El espacio de sus libros está formado por un lenguaje sin cabida en esa literatura que con efecto de gran dignidad moral llamábamos seria.

\section{Fotonevela. Caricatura. Burlas y piruetas}

La fotonovela es uno de los términos de esa división que los libros de Puig superan. Romances desesperados, sesudas conversaciones filosóficas en una peluquería acerca de la pérdida de la virginidad de una protagonista, palabras cargadas de miel y cursilería, fotografía ingenua, final feliz y lacrimógeno. Novelas para revistas leídas por empleadas domésticas, amas de casa, material que alimenta la pobreza intelectual, exagera las posibilidades de movilidad social, tine de color rosa la vida de sus personajes y ayuda a vivir amando los clichés y las grandes pasiones inofensivas. La fotonovela tiene sus lectores y su mundo de proyecciones ingenuas forma desde hace tiempo parte de nuestra vida cotidiana y constituye-junto con la novela rosa-una tradición literaria. Los personajes de fotonovela no se leen como caricatura. No hay la distancia, los elementos de tensión, que den cabida al humor, la visión crítica. Requieren una lectura de total proyección psicológica, un borrar relativo de las características de ficción. Relativo porque, a pesar de presentarse en un discurso terso y sin fisuras que permitan la visión humorística, se encuadran dentro de un género que se ve a sí mismo como marginal, como lo otro. Así, el mundo de las fotonovelas, historietas, novelas rosas son literatura especial, no seria; en la división en castas de la literatura ocupan un lugar de escasa dignidad. Sus verdades son puestas entre paréntesis por esa jerarquía: es lo que nos han enseñado a reconocer como mal gusto, aquello que por técnica y por distribución de lectores forma parte del mundo del consumo, literatura de encargo con funciones similares a las de las píldoras contra el insomnio. Así, la lectura de este tipo de obras es relativizada por el género al cual pertenecen y mientras se mantengan dentro de esos límites no presentan mayores problemas de interpretación. Julio Cortázar ha escrito fragmentaria pero repetidamente acerca de la incorporación del lenguaje coloquial en la literatura. ${ }^{2}$ Subyace en sus escritos la noción de que el uso del lenguaje coloquial eliminará el almidonamiento de la prosa. creará mejor literatura; habrá, en fin, novelas mejores porque estarán construidas con un lenguaje mas "natural". Necesidad de alcanzás suludez y cünisua las máscaras que se interponen entre la novela y la vida (vida no concebida de manera ingenua pero vida al,fin). Toda la obra de Cortázar está signada por ese gesto que trata de abrir la novela, quitarle artificiosidad y fisuras a su lenguaje. Su concepción dista de ser realista ingenua pero existe en ella, ciertamente, la tensión por encontrar modos de eliminar la distancia

2 Acaso más significativas que los textos donde este problema está tratado explícitamente sean las estructuras de sus obras Ultimo Round y La vuelta al día en 80 mundos donde ef fluir de lo escrito se propone como metafora de la libertad y espontaneidad del lenguaje oral. 
entre vida y literatura e, incluso, confundirlas. Literatura que se sabe limitada pero que encierra, todavía, su impotencia en un ejercicio dignificado de lectura. Tradición de ruptura ${ }^{3}$ con la literatura que se reinscribe en la literatura. Círculos. Encrucijadas. Y, sobre todo, gran huída del ridículo. La tersura, la neutralidad es un gesto de sobriedad anticolorista. Miedo a la cursilería, al poder oscurecedor de las frases hechas. El cliché, cuando aparece, está marcado con claridad y su función es sobresalir. El mal gusto está afuera y su estar adentro consiste en marcar su carácter ajeno, distante. La literatura de Cortázar, como la de Puig, es una literatura de transgresión. Pero las zonas que inauguran son bien distintas. En el sistema de oposiciones que hemos sugerido estos espacios se delinean con alguna nitidez. Calac y Polanco, en 62, Modelo para armar, son dos entes sobresalientes. Son exposición de porteñismos recortados del resto de la obra, elementos de heterogeneidad. La traición de Rita Hayworth, Boquitas pintadas y The Buenos Aires Affair ${ }^{4}$ no son obras heterogéneas en nuestro sentido del término ${ }^{5}$. Están escritas en un lenguaje homogéneo sin sugerencias de apertura: no hay una presencia tematizada de la literatura, juegos autorreflexivos, etc. Se presentan como obras no problematizadas con el lenguaje, seguras de la posibilidad de escribir y, como veremos, enmascarando el acto de escribir. Los personajes de estas novelas no adolecen de ese carácter difuso y cambiante de 62, Modelo para armar o las otras novelas de esa tradición. Su carácter ficticio está sostenido por una dialéctica de exterioridades no cuestionadas. Y, aún así, hay un hueco que forma la figura de la risa, instituye la posibilidad paródica, insinúa una posición con respecto al lenguaje. Pero la ubicación y calificación de ese momento es altamente problemática ya que la aparente neutralidad del discurso novelístico y su intrincada madeja de diälogos, clichés, lugares comunes de la cursilería, etc., oculta e imposibilita, a veces, el aislamiento de tales instantes. ¿ Dónde buscar, entonces, la fuente de la burla? ¿ Dónde encontrar aquello que dé cuenta de las trampas distanciadoras de Puig? La pirueta, la separación de la fotonovela y la novela rosa, la zona de ruptura, se va delineando en todas sus novelas. Acaso La traición de Rita Hayworth, por sus coordenadas obviamente cinematográficas, nos brinde algunas respuestas iniciales.

\section{Voces. Fantasmas. El cine de los ciegos.}

La novela se abre con una ausencia. Falta un narrador que, alejado de la "situación", nos la refiera. El lector sin guía, desamparado, se encientra frente a un

${ }^{3}$ Término acuñado por Octavio Paz y recurrente en sus escritos.

${ }^{4}$ La paginación que indicamos en nuestras citas de estas obras corresponden a las siguientes ediciones: La traición de Rita Hayworth, Buenos Aires: Jorge Alvarez, 1968; Boquitas pintadas, Buenos Aires: Sudamericana, 1973; The Buenos Aires Affair, Buenos Aires: Sudamericana, 1973.

${ }^{5}$ Además de lo sugerido ya en nuestra nota 1, el sentido de heterogeneidad abarca una tradición que, con un alto grado de generalidad, caracterizaríamos como de fisuras explícitas en la narración. Estos problemas que se refieren a las consecuencias de la literatura autorreflexiva iniciada por Macedonio Fernández son estudiados en un libro en preparación. 
diálogo con un título que es una breve acotación escénica: "En casa de los padres de Mita, La Plata, 1933.” (p. 7). Llamado a la visión. Ubicación geográfica e histórica. Notas de teatro. Acotación para una imagen en una representación que no se ve sino que se lee.

Primera ilusión: el escenario no se presenta por medio de una descripción sino que la acotación escénica exige uin proceso análogo al de estar presenciando una obra de teatro o la lectura de una fotonovela. Carácter enmascarado de una narración que comienza como si la presencia de los personajes fuera tangible, como si estuvieran ante nosotros en la actualidad de la foto o del escenario. Novela que se quiere algo distinto de sí y que construye sus convenciones en un ejercicio mimético de referencia a otros géneros.

Las voces introducidas por la acotación escénica son de fantasmas; no sabemos quién habla. Curiosamente, esa carencia de información no crea la tensión del misterio. No hay, desde el comienzo, una ilusión de individualidad psicológica independiente del diálogo. El lector es iniciado en el proceso del siguiente modo:

-El punto cruz hecho con hilo marrón sobre la tela de lino color crudo, por eso te quedó tan lindo el mantel.

Me dío más trabajo este mantel que el juego de carpetas, que son ocho pares. . .si pagaran mejor las labores me convendría tomar una sirvienta con cama y dedicar más tiempo a labores, una vez hecha la clientela $i$ no te parece?

-Las labores parece que no cansaran pero después de unas horas se siente la espalda que está un poco dolorida.

-Pero Mita quiere que le haga un cubrecama... (p. 7)

Dialogo que se alimenta de charla cotidiana y que, como inauguración de la novela, sirve de punto de partida de la lectura. ¿ Que nos dice este diálogo? La primera respuesta a esta pregunta se refiere al carácter negativo del comienzo:

.No hay narrador fuera de la "situación".

.No hay información acerca de los personajes.

.No hay un "tema" propiamente dicho, ya que el diálogo es proliferación de detalles caseros.

.No hay un escenario.

Este diálogo, ya intuimos la respuesta, no és acerca de nada. No está incluído dentro de una estructura mayor que le dé razón ni tampoco sirve para caracterizar a entidades - personajes - que el lector conozca ya como individualidades psicológicas. Está construído en un nivel en el cual resulta innecesaria - inexistente - la distinción entre contexto y personaje, acción y escenario. Es proliferación de lugares comunes cuya función consiste en presentarse, estar ahí, en un espacio que rehuye la deter- 
minación de distintos niveles de realidad en la obra. Evasión del centro. Lenguaje que asume la dispersión como arquitectura. ${ }^{6}$ Los únicos hilos conductores son el chisme, las ocupaciones diarias. Respuestas predictibles a la existencia, localismos, clichés, prejuicios pueblerinos que entran en la novela enmascarando indicios de traducción literaria:

-Tenía los ojos pintados como una gitana. Se habrá ido a encontrar con el hombre ese.

-Pero si es casado él debe estar cenando en la casa a esta hora.

-Se debe haber encontrado con algún otro.

-¿Qué querés que haga? Si vuelve a la casa lo único que encuentra es al . padre.

-Yo a veces pienso si las madres levantaran la cabeza de la tumba.

-Primero hay que barrer, después pasar el trapo así...

El enmascaramiento del carácter literario de esta transcripción de habladurias se realiza primariamente por la ausencia de una voz que narre y otorgue espacios y categorías a lo dicho. De este modo, el lenguaje se vuelve sobre sí y la digresión es asumida como una constante que cumplirá la función de mostrárnoslo. El carácter fantasmagórico de los parlantes se entiende, así, como necesidad para el cumplimiento de esta función: sus nombres son sólo pretextos, encarnaciones obligatorias que hacen posible el discurso. Pero este discurso no debe estar contaminado: será sin propósitos fijos, destematizado y sin productores bien delineados.

Ausencia de señales: el lector avanza en una novela construida con un lenguaje que tradicionalmente era "lo otro", aquello no literario convertido, así, en presencia legible y no mediatizado, todavía, por la sujeción a un argumento.

\section{Líneas argumentales. Construcción de pistas.}

La acotación escénica es ficción visual. Confunde un nivel gráfico con otro. Enmascara las palabras con la actualidad de la presencia fotográfica. Fotonovela sin foto. Novela-foto cuya narración se produce por un mecanismo de secuencias escénicas. En la sucesión de esas secuencias el lector encuentra las pistas que están explícitamente ausentes al comienzo. Las fechas que integran los títulos de capítulo son parte de una cronología. El punto de referencia de esa cronología es alguien que va emergiendo de ella con una caracterización de edades. El bebé que aparece mencionado marginalmente en las conversaciones de los dos primeros capítulos crece en los siguientes y del caos surge la figura del Toto. Toto: creado por la mención

${ }^{6}$ Esta dispersión se presenta como analogía del lenguaje oral. Aun cuando inscribe ciertos puntos de significación, estos participan de un juege con otros puntos de la misma naturaleza en un sistema que los equipara y cancela. Por eso no podemos hablar de un centro sino de puntos nodales de significación en una estructura descentrada. 
chismosa de otros al principio es el protagonista de este transcurso. El Toto crece en la novela y, hasta cierto punto, la novela es la historia de su crecimiento. ¿ Como surge su figura en este discurso fantasma? El Toto alcanza la individualidad permitida por la corriente de coloquialismos; es otra manifestación del lugar común. Crecer es, para él, el pasaje de bebé-mención a productor de clichés.

La convención es todopoderosa, omnipresente. En ningún momento, sin embargo, es vivida como círculo. Este discurso se postula como el único posible, alternativa obligatoria nunca cuestionada. La ausencia de cuestionamiento se revela, entre otras cosas, en la falta de niveles de profundidad en el texto:

Que en el fin del mundo se van a quemar, la Paqui se va a morir aplastada entre las bordalesas que después se la comen los ratones, Raúl García partido en dos por el hachazo que le pega uno del negocio cuando lo ve que se metió en el patio, y Luisito Castro se hunde en un pozo hirviendo de cal y les cae encima la lluvia de gotas de fuego, que quema a los malos nada más, los buenos están en unos campos de lomitas de Holanda esperando el juicio final, y ahí no hay más peligros: que por donde camina el que se casó con la tía de Alicita las gotas de fuego no queman, se vuelven plateadas y livianitas como papel picado, y yo doy un salto desde este zaguán tan oscuro y él me levanta en brazos, los ojos colorados le digo que son irritados de conjuntivitis. .

(pp. 101-2).

Sabemos que es el Toto quien produce este discurso pero nada en su postulaciónexcepto la certeza de que está solo-nos permite decidir si está hablando con alguna otra entidad o si, de esta manera, estamos siendo introducidos a su "vida interior". Es que la existencia misma de la vida interior ha sido puesta entre paréntesis. El lenguaje de la intimidad y el público han sido fundidos. Los clichés no son sólo un instrumento de comunicación con los otros que permite eludir el peligro de encuentros más profundos y riesgosos; no son escapismo del lenguaje privado ya que no hay tal lenguaje. El subconsciente no es una zona con su propio idioma, está absorbido por los lugares comunes. Es exterioridad; no hay diferencias entre su diccionario y el del chisme. No existe una decodificación propia de este pensar en soledad que califica la existencia de una persona singular, privada. ${ }^{7}$ Esta primera persona no se manifiesta originalmente; es internalización de lo Mismo, producción

7 Dentro de las consecuencias del así llamado discurso de flujo de conciencia está la ilusiơn de profundidad. La manera en que el subconsciente ejerce su habla lo caracteriza como individual, personal. As I lie dying de Faulkner es el ejemplo acaso más extremo de una literatura que postula la existencia de un lenguaje profundo y privado. En esa novela adivinamos la identidad de los personajes por sus discursos interiores, nítidamente recortados unodelotro. Puig elabora sus novelas en contra de esta concepción de profundidad, de niveles dentro de los cuales es posible reconocer una persona privada. 
de lo Mismo. Este hipotético yo ni siquiera existe como hipótesis en la novela. Pero el lector se ve forzado a pensar en esos términos porque la literatura contemporánea se ha dedicado al encuentro de este yo y ha experimentado con discursos que lo expresen: la escritura automática, el flujo de conciencia, etc. (para usar el vocabulario introducido por críticos temáticos y estilistas con no poca ingenuidad). De modo que es inevitable considerar estos momentos en ese sistema de oposiciones y convertirlos, por esa lectura, en un ejercicio crítico, una ruptura. Ruptura de la interioridad, inauguración de un sistema por el cual el discurso del yo interior es equiparado con el del mundo exterior. ${ }^{8}$ Ese proceso de equiparación está calificudo por la negativa de construir un discurso privativo del yo. Círculo formado por lugares comunes herméticamente cerrados, ciegos con respecto a la existencia de otras posibilidades. No hay manifestación de lo interno; el lenguaje no es ex-presión. Todo se incorpora desde afuera; hablar, vivir, pensar es participar de esta radical exterioridad.

La existencia de líneas argumentales comienza ahora a mostrarse en toda su ironía. i En qué sentido podemos, complementariamente, hablar de personajes? Los personajes, el personaje Toto, tiene una existencia ciertamente curiosa. Crece a lo largo de la novela y en ese sentido es la línea que da razón a los cambios de fechas, aquello constantemente en circulación dentro de la sucesión de detalles. Pero, al mismo tiempo, su individualidad consiste en su generalidad. Su lenguaje es el de los otros y lo único que conocemos y existe de él para nosotros es su lenguaje. Al decirse, el Toto dice al mundo exterior, al nombrarse se representa en los lugares comunes. El Toto existe como combinación de los otros: madeja de clichés y adocenamientos. Esto nos lleva al problema del carácter de la representación del discurso en la novela.

\section{Realidad fotografica. Repeticion y diferencias.}

El cine no es simplemente un tema recurrente en la novela. Los personajes no sólo hablan de cine sino que se construyen por esa referencia. Sus conversaciones y su imaginación están regidas por las leyes del gusto que definen a las estrelles de cine, sus pasiones por la semejanza con ciertas películas, sus pesadillas por el colorido y densidad de esas imágenes. Su mundo interior es, así, también obra de la incorporación de elementos considerados exteriores. Sus vidas son adocenadas, sus ilusiones de individualidad son incorporación de la exterioridad del consumo. El mercado les brinda películas y gracias a ellas elaboran fantasias: logro de la individualidad por un ejercicio de imitación:

-Una buena base de crema en la cara y casi sin colorete (es mejor. pálida, más interesante) y después mucha sombra en los ojos que da el

${ }^{8}$ E. Benveniste ha establecido los términos de la relación entre interioridad y exterioridad inscriptos en el discurso debido al juego generado por el uso de pronombres personales. Ver especialmente en su libro Problémes de linguistique générale(Paris: Gallimard, 1966) el capitulo titulado "L'homme dans la langue", p. 225-289. 
misterio de la mirada y cosmético renegrido en las pestañas. ¿ Sabes una cosa? Todos los peinados de Mecha Ortiz me quedan bien. No hay artista que me guste más, entre las argentinas.

"Ser interesante" es construir una imagen que afirme la dependencia con respecto a otra imagen, parecer ser uno mismo por la semejanza con otro que, hipotéticamente, es un individuo.

La realidad de los personajes (la tensión de su deseo) es imitación fotográfica. No sólo encontramos un nivel en el cual el discurso de la novela nos hace ver, se nos presenta en un ejercicio mimético de otros géneros gráficos; este principio estructurador rige tambiēn para la construcción de los personajes. Se ven a sí mismos como imitación; su existencia e individualidad son definidos por el como si. Novela-foto, personajes que se creen cinematográficos, definición por lo que no es, negatividad: convención construida sobre un hueco.

La sexualidad de los personajes es otra instancia del hueco. Los romances son imitación de las películas, los encuentros y desenlaces se piensan cinematográficamente:

Y no lo esperaba en el zaguán, lo esperaba en la esquina, así lo veía venir desde una cuadra de distancia, que se iba agrandando hasta que cerca mío yo empezaba a retroceder y empezaba a contar uno, dos, tres, cuatro. . .el tiempo que faltaba para que me alcanzara. . .y de chiquito que estaba en la esquina lejos ya está delante mío que me tapa todo lo que hay delante, me tapa todo con la cabeza y el cuello y las hombreras, pero yo le miro los ojos que se le refleja el piso encerado del zaguán, y en el piso encerado se refleja un hombre que es él, dónde empieza él y dónde termina el piso no se sabe. . .

(p. 140)

La representaciōn cinematogrăfica dibuja figuras en la novela. Las relaciones eróticas son unidad de un imitador con un modelo artificial, surgido del cine. Y no dejan de ser significativas las fechas de ese cine: películas que hacen de la artificiosidad su mayor virtud; rechazo del realismo en favor de una estructura que ordena grandes pasiones por medio de clichés y shows musicales. ${ }^{9}$ Las peliculas imitadas son, también ellas, portadoras de la tensión con respecto a sus referentes.

\footnotetext{
${ }^{9}$ Las obras de Puig como las de otros autores hispanoamericanos pero más intensamente, se emparenta con el melodrama. Las películas de los años treinta, los folletines, las fotonovelas, el tango participan de esa rica cultura melodramática y popular tan poco estudiada en nuestra tradición.
} 
Los personajes tienden a presentarse como caricaturas huyendo prolijamente del realismo que predominará en años posteriores, Así, la novela de Puig constituye una suerte de lenguaje de tercer grado al repetir la separación que las películas imitadas guardan con respecto a sus referentes externos. Fotografía de fotografía, repetición de la repetición. La escritura de la novela repite la enajenación de los personajes. Por eso es erróneo caracterizar a La traición de Rita Hayworth como una obra que trata de la alienación de ciertos personajes en el cine. Este no es el tema ${ }^{10}$, es el principio estructurador de la obra que, precisamente por ello, no lo trata como tema sino que lo produce como efecto de su escritura. Los clichés, la radical convencionalidad de la cursilería de La traición. . . no guardan con respecto a esa hipotética enajenación de los personajes la distancia que permita decir que nos encontramos ante el tratamiento de un "tema". Si hay momentos en los cuales la novela piensa, reflexiona, sobre la naturaleza de su propia representación estos asumen la figura de la multiplicación de ese repetir, imitar, depender: "Sin modelo no sé dibujar, sin modelo mamá sabe dibujar, con modelo dibujo mejor yo..." (p. 73). No hay una voz distanciada de la ficción que comente sobre los personajes. La presentación del carácter ficticio de lo que sucede en el texto es el efecto de la multiplicación de instancias en las cuales se copia, se dibuja, se imita. Cada momento del libro es idéntico al otro en ese sentido; la homogeneidad es sorprendente, cada nivel repite y contiene a los demás: la escritura imita a un género o a varios a los cuales no pertenece (el cine, la fotonovela) los personajes imitan a actores que a su vez imitan - oblicuamente - a seres reales; las así llamadas acciones son repetición de otras vistas en el cine. De ese modo resulta difícil hablar de progreso, transcurso o narración (en el sentido de desarrollo) en $L a$ traición. . La novela es una obra sobre el novelar visto como construcción de una ficción que está indisolublemente alejada de aquello sobre lo cual habla. El lenguaje guarda una relación especular con lo que nombra, pero sólo puede nombrar y no sustituir a su referente; sólo puede indicar que en la repetición existe una diferencia, un hueco por el cual lo Mismo es siempre lo Otro.

El Toto no puede tirarse a la pileta: "yo no le tengo miedo al agua, lo que le tengo miedo es al fondo de la pileta" (p. 141). La novela de Puig es ese miedo al fondo de la pileta; un gesto que trata de evadir la mención de ese fondo por medio de la artificiosidad, el cliché, marcando su radical inadecuación al referente. La traición de Rita Hayworth es, así, una novela construida sobre un hueco, sobre la negativa a tirarse a la pileta, hacer el amor; una reflexión sobre un lenguaje que no es puente sino repetición de los têrminos de su impotencia.

10 La palabra tema, tal como ha sido utilizada en la critíca literaria hispánica, evoca una noción atomística del texto. Supone la existencia externa, anterior a la obra misma, de un ente llamado tema que después se encuentra en la novela. El lenguaje en que se nota este tipo de lectura evidencia claramente este mecanismo: el tema de la muerte en tales y tales obras. Apriorismo que conlleva una lectura atomística ya que supone una división del texto en temas, argumentos, personajes, etc., etc. Pensar en efectos que juegan dentro del discurso novelístico generados por las voces de la narración implica una actitud polémica con respecto a las lecturas "temáticas". La noción de efectos tematicos señala la estrecha dependencia que los momentos de la narración crean entre sí, en un juego inter-textual. 


\section{Lo Mismo y lo Otro: hacer el amor, tirarse a la pileta.}

En La traiciōn. . . el único erotismo triunfante - con objeto aparentemente conquistado - es el del Héctor: desvirgador deportivo, versión del macho bruto, pareja en el juego de oposiciones Toto-Héctor. Pero así como la incapacidad del Toto es general, abstracta, idéntica para todos los objetos con los cuales hace contacto, la potencia del Héctor es abstracta, indiferente a los cambios de muchachas. El Toto no puede hacer el amor (sólo puede llegar a convertirse en víctima) pero posee la capacidad de copiar que - como ya hemos intuido - es precisamente la posibilidad de hablar, imitar, ejercer la posesión del lenguaje. El Héctor es mudo. No entiende las películas, no entiende las novelas que le prestan las muchachas. Es incapaz de construir una relación imitativa con los modelos del Toto. Pero, aún así, está también signado por la repetición ya que su fisonomía es reactuación de una instancia básica: desvirgar. El erotismo de uno y otro funciona como un límite, un marco de referencias en el cual se inscribe el del resto de los personajes.

El miedo a tirarse al agua para encontrar el fondo de la pileta es el eje del discurso de Boquitas pintadas.

Las obras de Puig dialogan entre sí para construir un gesto complejo con respecto al lenguaje visto como tensión erótica (tensión del deseo). Por eso sugerimos una lectura triple que mostrará la problemática ciertamente similar de los tres textos que Puig ha producido hasta el momento.

Boquitas pintadas se presenta como folletín y de ese modo reproduce el enmascaramiento que habíamos notado en La traicion. . . con respecto al cine y a la fotonovela. Es una obra que se quiere algo distinto de sí, de su ser novela. Los tangos de Le Pera cumplen para esta obra el papel que las películas cumplieron para $L a$ traición. . . Los amaneramientos y convencionalidad general de ese cine se corresponden con la artificiosidad de las letras de Le Pera que no podemos evitar sentir cantadas por la voz de Carlos Gardel. Y ese tango es opuesto al realismo y al "sentimiento"; sus juegos verbales, su cursilería, marcan la conciencia de su propia exageración. La voz irónica de Gardel con su relación siempre oblicua con respecto a lo cantado agrega un nivel en el cual el tango se contempla a sí mismo, complementando, así, la artificiosidad de las letras de Le Pera.

Las fechas que cırcunscriben la época de la novela son, tambiěn, parte del gesto convencional. Debemos ubicarnos en los años treinta ${ }^{11}$ y como resultado de esa ilusión, de esa violencia sobre la realidad, surge otro efecto de distanciamiento. En La traición. . . los personajes aprenden a hablar y vivir copiando del cine. En Boquitas pintadas van a aprender a escribir. La traición. . . comienza con un juego de voces y se estructura para mostrar el lenguaje oral en su tensión imitativa. Boquitas pintadas se abre con un verso de Le Pera;:"Era para mí la vida entera”y una

\footnotetext{
11' La ubicación en un año, una época determinada, en las novelas de Puig exige la participación del lector en las ilusiones generadas por la cultura popular en bóga. Es aceptación de una moda anterior con el reconocimiènto de su carácter convencional, "vestirse de épocă".
} 
nota necrológica. A continuación siguen unas cartas. Las cartas hablan, sobre todo, de sí mismas pues si bien tienden a enhebrar una historia hay un solo lado mostrado en la primera y segunda entregas. Sólo leemos las cartas de Nené; sólo conocemos el gesto por el cual el escribir tiende al otro, a llamar el discurso del otro. De las primeras dos entregas conocemos la tensión de Nené por rememorar y establecer contacto con la madre de Juan Carlos. Tensión hacia atrás : el pasado, reconstruir la figura de un muerto y tensión hacia el futuro: elaborar un discurso que provoque señales fuera de sí mismo, hacia sí mismo. Por eso Boquitas pintadas se inicia con textos que podemos llamar de autoexamen. La carta se muestra a sí misma como puente e interrogación de una realidad definitivamente perdida. La pérdida del objeto erótico guarda una relación especular con el miedo al fondo de la pileta del Toto. Pero hay diferencias con La traición. . .; los personajes parecen haber vivido un romance"real"no imitado de películas. La manera en que éste nos es presentado, sin embargo, lo convierte en igualmente imitativo porque la escritura no asume la actualidad como espacio para lo narrado. No habrá transcurso propiamente dicho en la novela porque ya ha ocurrido todo antes de su comienzo. Los desenlaces están presentes en la nota necrológica, en la situación de quien firma las cartas. El discurso de Boquitas pintadas está divorciado, distanciado de la "realidad" por el tiempo y la artificiosidad de las cartas. El romance ha sido perfectamente fijado por la muerte. Y eso hace de él una figura acabada, un argumento que funciona como una película. Las cartas miran esa realidad perdida y, en su esfuerzo por recobrarla, marcan el espacio de separación por el cual Nené es constantemente otra, distinta de una joven que vivió un idilio narrado nostálgicamente en Boquitas pintadas. La nostalgia, la conciencia de la distancia por esa época y esa figura acabada son similares a la relación con las películas. En La traiciön. . . el cine está tan cerca o tan lejos como el pasado en Boquitas pintadas. Otra vez, entonces, un discurso que hace de la incapacidad por confundirse con el referente su eje organizador. Tampoco habrá transcurso porque los datos están dados desde el comienzo ${ }^{12}$ y la novela se desarrollará co $4_{-j}^{8}$ el examen de su impotencia por anular la diferencia, el intersticio, que la separan de su referente. Los líos amorosos oscilaron alrededor de la calidad de las relaciones eróticas entre los personajes. Juan Carlos es otra versión del Héctor, de un Héctor mayor perseguido por la muerte y la impotencia. El macho Héctor no leia, el macho Juan Carlos no sabe escribir y su relación difícil con el idioma es un juego que muestra, también, su erotismo abstracto: la ausencia de un objeto sexual que dé dirección única a su deseo.

Boquitas pintadas está construida por la tensión de recordar algo, de apropiarse de algo pasado. El carácter irreversible de su pertenencia al pasado dibuja la necesidad de un sistema de convenciones que lo refiera. Y ese es el sentido que adquieren las cartas. Al mostrar un solo lado de la correspondencia las cartas se delinean como un puente carente de uno de sus extremos. Las cartas son, en prin-

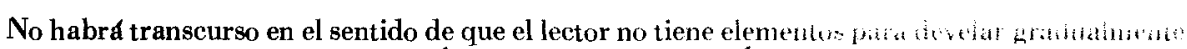
un "argumento". La novela consistirá de otra cosa, postulará otros materiales para elaborar la ilusión de "progreso". 
cipio, la frustración de una relación equilibrada entre emisor y receptor. Pero las respuestas han existido; Nené ha recibido otras cartas. Nosotros no las conocemos pero la mencion que de ellas hace Nene en las suyas crea una ilusion de profundidad; hay datos que existen y permaecen escondidos. Las cartas de Nene, en este sentido, operan no solo como intento de re-vivir (contar un romance) sino tambien como reescritura de las cartas de la madre de Juan Carlos. Sus cartas son, asi, un hueco con alusiones hacia el pasado al mismo tiempo que tienden una linea de comunicacion con una hipotetica escritora de respuestas (despues comprendemos que no es la madre de Juan Carlos quien escribe las cartas) que trata, a su vez, como ella, de capturar otra version de ese pasado.

Advertimos que en la novela no pasará nada. El carácter rememorativo de su discurso indica que sólo presenciaremos un gesto que trata de capturar algo que no estáahí. El referente de Boquitas pintadas está muerto, su movimiento no podrá ser devuelto, funciona como una figura estática. ¿De dónde proviene ese estatismo? ¿Por qué no podemos decir, como con respecto a otras obras, que a pesar de que el referente esté en el pasado hay una ilusión de presencia creada por un discurso que le otorga las tensiones de la actualidad? Un juego de fechas ayuda a crear la conciencia de esta ausencia radical. El lector lee este libro en los setenta, lo narrado por la voz que escribe las cartas ocurre en los treinta y la voz que lo narra lo hace en los cuarenta. Hay un enmascaramiento inicial al ubicar a la voz responsable del discurso en una fecha que hace de su narración el efecto de un tejido convencional. Esa voz es, ya, resultado de la reconstrucción arquelógica de un lenguaje y - en ese sentido - cosa muerta, artefacto. La reconstrucción arqueológica que la voz arqueológicamente reconstruida intenta es - como efecto de la diferencia en el nivel de repetición doblemente convencional.

Por eso el romance de Boquitas pintadas está muerto con la convencionalidad de las películas que ven los personajes de La traición. . . El Toto y el Héctor son dos extremos de la incapacidad de hacer el amor que, para notar la relación especular con la estructura novelistíca, habíamos sintetizado en la incapacidad para tirarse al fondo de la pileta; Boquitas pintadas presenta la misma incapacidad. Juan Carlos ha hecho el amor con varias mujeres de la novela pero esto nos es filtrado por un sistema de convenciones que introduce una relación de distancia con respecto a la " realidad ". Las voces que nos hablan son incapaces de escribir bien (presentar ese pasado irremediablemente afueral y, también, de vivir un romance que compita con el que evocan. Son, esencialmente, voces muertas. Esto es efecto de la reconstrucción arquelógica que las crea. Ciertos fragmentos de la novela se presentan como modelos en menor escala del mismo procedimiento:

El tango narra la desventura de un hombre que bajo la lluvia invernal recuerda la noche calurosa de luna en que conoció a su amada y la subsiguiente noche de lluvia en que la perdió, expresando su miedo de que al día siguiente salga el sol y ni siquiera así vuelva ella a s $\not$ lado, posible indicio de su muerte. Finalmente pide que si el regreso no se produce, tampoco vuelvan a florecer los malvones del patio si esos 
pétalos deberán marchitarse poco después.

\section{(pp. 14-15)}

Contar el tango es perderlo. La prolijidad escolar con que se lo narra destaca aun más la violencia de la traducción. Todo intento de captar algo qụe está afuera del discurso se anula por el carácter convencional, artificioso, de la inscripción.

Las cartas, las fechas, la arqueología de Puig en Boquitas pintadas son una formulación de la pérdida del referente en el ejercicio de escritura.

\section{Ver y recitar: The Buenos Aires Affair}

The Buenos Aires Affair se propone como novela policial. Como Borges ha señalado no pocas veces, esto indica que estaremos ante un texto que es trama. Y, también con ecos definidamente borgianos, encontramos un tejido policial que se niega a sí mismo con la falta de realización del crimen. Novela, entonces, que se ubica oblicuamente con respecto a un género. Un modelo para la muerte ${ }^{13}$ de Bioy Casares y Borges parece ser el modelo implícito en la construcción. Como en esa obra encontraremos aquí un acercamiento altamente complicado a la "realidad".

Los personajes de Puig han cambiado en The Buenos Aires Affair. Se ha producido un salto cualitativo. La artificiosidad que tendía a presentarse como exageración en las novelas anteriores ahora se convierte en esencia de los personajes. El personaje femenino de The Buencs Aires Affair carece de un ojo y el que le queda está maquillado de manera tal que produce un efecto de irrealidad. Las películas que aparecían mencionadas en La traición de Rita Hayworth son integradas ahora al texto por medio de fragmentos de diálogo. Esas películas son extranjeras, leemos las traducciones. El título mismo del libro es extranjero. La artificiosidad del género policial (el carácter de construcción de toda trama y, así, volvemos a Bioy y Borges) se sintetiza en las figuras de los personajes y en los diversos niveles en los cuales el lenguaje se presenta como dependiente de otro nivel, también convencional.

La madre de la protagonista recita poemas, los declama. En The Buenos Aires Affair los personajes saben leer, escribir y tratan de hacer"arte". ${ }^{14}$

Si en las otras dos novelas había un gesto que tendía a la verosimilitud en ésta es sustituido por una estilización y condensación de los rasgos que antes aparecían como abstracción o tipificaciones. Los personajes masculinos que dibujaban la impotencia son ahora la mujer, Gladys, que trata de ser escultora. Las madres de las novelas

13 Jorge Luis Borges y Adolfo Bioy Casares, Un modelo para la muerte (Buęnos Aires: Edicom, 1970). Los entrecruzamientos, ironías, autoparodias de esta obra exceden los alcances de este trabajo. Anotemos sólo que existe una analogía entre la posición que la obra de Puig y la de $\mathbf{B}$. Suárez Lynch eligen con respecto al género policial.

14 Arte entre comillas porque aparece desacralizado y puesto en una situacion que to hace aparecer con una calidad degradada, equiparado con la moda, la escritura de cartas de amor, la lectura de María, etc. 
anteriores pasan filtradas como parte de una relación madre-hija en vez de madrehijo. La madre del Toto es, de algún modo, receptáculo del mundo de los referentes al ser la mejor cuentista de películas, la compañera ideal para ver y comentar la fuente de las fantasías, el punto de origen de la representación de segundo grado. La madre de Juan Carlos (madre "ficticia"; escritora de cartas a través de la hermana que asume su identidad al firmarlas) ocupa el mismo lugar al poseer la correspondencia que fija materialmente el romance de Juan Carlos y Nené evocado en la novela. La madre de Gladys es, ella misma, un nivel de representación. Piensa con poemas. Su pensar más privilegiado es un ejercicio de recuerdo:

Levantó la persiana y miró a lo alto, de su memoria brotó otra estrofa, "cerraron sus ojos / que aún tenía abiertos; / taparon su cara / con un blanco lienzo / y unos sollozando / otros en silencio / de la triste. ..de la triste alcoba / todos se apartaron...' Cada vez que lugraba recordar sin esfuerzo un trozo de su repertorio Clara Evelia se sentía reconfortada, tantos años había sido profesora de declamación. . .

(p. 10)

Clara Evelia es profesora de declamación; como las otras madres de Puig es punto de origen de las fantasías que funcionan como referentes en el texto. El salto cualitativo con respecto a las otras se revela en el carácter "profesional" de esa función: es profesora de declamación. Por un sistema similar de cambios cualitativos los hombres de las novelas anteriores pasan a esta en el personaje de Gladys: mujer que ha sufrido la pérdida de un órgano esencial, el ojo. Pero ha ganado un ojo de vidrio que se coloca sobre el hueco, como ornamento:.“...con esas pestañas postizas importadas el ojo puede destacarse más y resultar de una belleza radiante, el ojo celeste con el párpado verde y las pestañas azabache como las alas y la colita erguida del colibrí."(p. 16). El ojo ha sido perdido en un intento de violación ocurrido en Estados Unidos; los ecos del Toto (víctima constantemente tensa de violaciones pendientes) resultan obvios.

La madre no habla, recita. La hija ve con un solo ojo. Pero es vista con dos. Su pareja de ojos es resultado de la artificiosidad del agregado de vidrio; su cara es engaño, ceremonia: "Un joven llegó a decirle que ese ojo parecía un colibrí posado en su cara. ..” (p. 16)

Los personajes no están 'alienados'; son, ellos mismos, fetiches. Tienden a lo inanimado, la estatua. Clara Evelia es una colección de remanidos poemas, Gladys un artificio tan convencional como sus propias obras de arte.

Regreso al cine de los ciegos: ojos y ojo.

No pudo frenar un fuerte deseo de masturbación. Le sobrevino un 


\begin{abstract}
orgasmo rápido y fuerte, había logrado visualizar a Leo penetrándola y sonriéndole dulcemente, algo que sólo había hecho simultáneamente la mañana anterior, en presencia de María Esther.

(p. 246)
\end{abstract}

Gladys puede tener orgasmos, relacionarse individualmente con personajes masculinos, masturbarse. Su cara es, ella misma, efecto de un intento de acto sexual. Gladys está signada por la posibilidad del acto sexual. El Toto, el Héctor y Juan Carlos están transfigurados en este personaje femenino cuya sexualidad repite y niega simultáneamente la impotencia que habíamos notado en los textos anteriores. El Toto y el Héctor son determinaciones opuestas en una línea que frustra la consecución de un objeto erótico individualizado. Juan Carlos es mención muerta de un romance que al ser referido lo estatiza y convierte en artefacto. Las determinaciones de Gladys tienen otro grado de complejidad. Sus orgasmos son efecto de una representación. Su placer es visualización, aprobación de una fantasía que le permite observarse en un espacio en el cual construye una relación fantasmática con alguien que es siempre otro. $\mathrm{O}$ sintiéndose observada por otro que confirma el coito como espectáculo, representación, show. De ahí la necesidad de la presencia de María Esther para alcanzar el orgasmo en el momento del coito y, también, para repetirlo convirtiéndose ella en observadora de la relación triple que hace posible su placer.

La relación erótica es, así, espectáculo. El orgasmo es efecto de representación, resultado de un lenguaje. Por eso la manera de conseguirlo es siempre oblicua y mediatizada. Los cuerpos participantes son soporte para un sistema artificioso de relaciones; sirven para construir otra cosa, distinta de ellos que al mismo tiempo los devuelve a sí mismos. Este retorno de lo Otro a lo Mismo ${ }^{15}$ es posible por un lenguaje, una ficción. Gladys se masturba en unas páginas que muestran las posibilidades paródicas de esta noción de orgasmo mediatizado:

Si intentase desprenderse de él sería muy posible que no lo lograse y ello podría en cambio redoblar su ímpetu masculino. Si ella saca la conversación de la delincuencia juvenil y la conveniencia de que los niños de él no crezcan en un suburbio de averías es posible que él no responda porque le disgusta hablar de ese tema pero si ya han pasado algunos minutos es posible que ella se esté acostumbrando a la corpulencia de él y le proponga acompañarlo a los cursos gratis de inglés que se dictan en todos los barrios de Nueva York porque

${ }^{15}$ Gilles Deleuze ha estudiado los juegos de repetición en el seno del lenguaje y la historia en su libro Différence et répétition (Paris: Presses Universitaires de France, 1968). La bibliografía incluida como apéndice a la obra es útil y exhaustiva, el lector interesado en estos problemas puede consultarla para más información. 
haciendo un sacrificio todos los días después del trabajo podría salir de su estrecha condición de peón, terminar la escuelạ que nunca hizo, trabajar con cuello y corbata en vez de overol. (pp. 75-76)

La narración que constituye la fantasía masturbatoria separa y devuelve a Gladys a si misma al representarla en la tercera persona del singular ${ }^{16}$. Los sucesos, las imágenes que componen la fantasía están tan alejadas de una finalidad erótica que la excitación que producen es parte del efecto de distancia humorística del fragmento ${ }^{17}$.

Los ojos, la voz de Gladys sirven para relacionarse con algo que no está ahí. Su excitación erótica es efecto de una ausencia, de una redefinición de los referentes como espectáculo, la construcción de un artefacto.

\section{El Lujo de la castración.}

$$
\begin{aligned}
& \text { Y la península párase } \\
& \text { por la espalda, abozaleada, impertérrita } \\
& \text { en la línea mortal del equilibrio. } \\
& \text { César Vallejo }
\end{aligned}
$$

Las novelas de Puig existen en un espacio que cuestiona la articulación del la:nguaje con sus referentes. Se instalan precisamente en la línea de demarcación que inicia la construcción de niveles de convencionalidad. Desde el subtítulo de las obras que tiende a ubicarlas en un género con el cual guardan una relación oblicua IBoquitas pintadas, folletín; The Buenos Aires Affair, novela policial; La traición de Kita Hayworth sin subtítulo pero con obvias afinidades que hemos señalado con la fotonovela) hasta la figuración de los personajes como voces imitativas, existe la imagen de una escritura que fracasa, se frustra en su gesto de captación de un referente y, al hacerlo, convierte esa frustración en condición de su existencia.

La recurrencia de la tensión erótica como posibilidad misma de la voz que, multiplicada, construye la narración abre un sistema de analogías: referente-cuerporealidad-otro; escritura-acto erótico-eliminación de la diferencia; consecución de lo mismo.

La voz que ordena el discurso es un fantasma, un efecto del juego intertextual que crea como punto de tensión. En las novelas de Puig se ha perdido la posibilidad de una mirada, de un ojo que dé unidad a lo escrito. Lo percibido, lo puesto sobre el

16

Benveniste estudia, en la obra ya citada, la función de la tercera persona del singular en la construcción de un discurso que la representa. El alcance, aparentemente modesto, de los estudios sobre la gramática francesa de Benveniste es interesante e ilumina ciertos aspectos determinantes del juego de voces en la narración.

17 El reconocimiento de la representación construye el efecto de distancia. 
papel es un lenguaje que no reconoce un único sujeto responsable. El mal gusto también ignora otra presencia: la de la tradición "literaria". En su aparente inocencia esconde la pirueta convencional. Las frases remanidas, la afectada elegancia, el intelectualismo de algunos personajes son una parodia de la literatura "digna"en general. Al mostrar la zona, el intersticio que separa a la literatura de sus referentes propone a sus novelas como una muestra de aquello a lo cual tiende toda escritura : la apropiación de algo que le es exterior y la transformación de ese algo en otra cosa que se presenta como lo mismo pero que sólo puede hacerlo gracias a la radical diferencia que guarda con respecto a su referente.

Pérdida de la voz ordenadora, pérdida del referente, consecución de una escritura. Enumerar estas instancias es mostrar la precariedad del acto de escribir. La escritura de Puig hace de esta castración ${ }^{18}$ la condición misma para el logro de la obra. Es por la falla, por la pérdida de la imagen que la convención existe como tal. La convención, la obra de arte es el producto de una carencia radical que la marca. Esa falta inaugura la posibilidad del exceso, la frivolidad, el artificio.

Puig es un escritor frívolo en un sentido ciertamente no peyorativo del término. Su lenguaje es reconstrucción arqueológica del de otros ${ }^{19}$, el carácter convencional está siempre marcado. Su nostalgia por otras músicas, otros años, otras películas es parte del ir hacia atrás para instalarse en momentos privilegiados en los cuales el lenguaje fracasa al querer construirse como sentido. Su escritura produce artefactos, piezas estáticas de museo, grandes pinturas idiomáticas. Ese es el lujo de la pérdida del referente: la posibilidad de pintar una y otra vez instancias de la misma fisura.

\title{
The Johns Hopkins University
}

\author{
Alicia Borinsky
}

${ }^{18}$ Usamos la palabra castracion para notar la pérdida del sujeto como ente que hace de su relacion con lo que le es exterior un proceso de apropiación. Esta noción que generaliza y desplaza el significado de castración como pérdida del órgano masculino a otro nivel: el de relación con todos los referentes externos, aparece en la obra de Freud (ver su curioso texto sobre la literatura "fantástica") y ciertamente en la de Jacques Lacan.

$19 \mathrm{El}$ papel estatizante de estas construcciones que denominamos arqueologiras merece atencion. La obra de Alejo Carpentier evidencia este gesto dirigido, en su caso, a zona " "rivilegiada" "de la cultura; Lezama Lima trabaja con un mosaico altamente complicado de cubanismos y cultura occidental filtrados a la narración como objetos de museo; podríamos seguir elaborando una lista de variaciones de estos mecanismos de construcción. Sollo nos interesa apuntar en este momento que éste no es un rasgo privativo de la obra de Puig. 
